\title{
Power System Distortion Mitigation by Using Series Active Power Filter
}

\author{
Muhammad Ossama Mahmoud ${ }^{1, *}$, Wael Mamdouh ${ }^{2}$ and Hamdy Khalil ${ }^{3}$ \\ 1 Department of Electrical power and machines, Faculty of Engineering, Ain-Shams University, Abbasia, Egypt \\ 2 Electrical Engineering Department, Egyptian Academy for Engineering and Advanced Technology, EAE\&AT, \\ Al-Salam City, Egypt \\ 3 Department of Electrical power and machines, Faculty of Engineering, Ain-Shams University, Abbasia, Egypt \\ * Corresponding author: eng_muhammad100@yahoo.com
}

\begin{abstract}
The power quality improvement faces different significant problems due to the wide use of power electronics and voltage instability. To overcome these different power quality problems, an active power filter is used. The active power filter in general has four main categories, shunt, series, unified power quality conditioner and hybrid active power filter. The shunt active power filter is usually used to mitigate source current harmonics and compensate reactive power for power factor improvement. The series active power filter is usually used to mitigate voltage problems (sags, swells, transients, dips, distortions....). The unified power quality conditioner is used for all voltage and current problems. In this paper, the three phase three-wire series active power filter is utilized alone to mitigate all power system problems (voltages and currents) for this case study, such as voltage sag, voltage swell, voltage harmonics, and source current harmonics to comply with the harmonics limits given in IEEE 519-1992, and IEC 61000-4-7 standards. The source current harmonic problem mainly exists due to, 1) distorted voltage source, and 2) non-linear loads. The series active power filter can effectively eliminate the source current harmonics in case of distorted voltage source. Consequently, the series active power filter can be used alone as a power quality improvement for all voltage and current problems as mentioned in this case study.
\end{abstract}

Key words: Series active power filter-Non ideal voltage source-Current harmonics-Voltage harmonicsMATLAB SIMULINK-THD.

\section{1- Introduction}

Power quality is the trend and the most important issue in electrical power systems. Power quality in simple words means the voltage quality generated and supplied to the whole electrical power system parts [1-7]. It determines the fitness and health of electrical power system. The main reasons of poor power quality are distortions in voltages and currents waveforms. The distortion in voltage and current is occurred because of voltage source problems (mains) and load problems (non-linear and unbalanced loads) [8]. The Active power filter is the one of the most effective solutions to overcome all power quality problems [9-16]. By using different categories of active power filter, the power quality will be improved and customer will get a good power quality at the point of common coupling (PCC). Each category of active power filter mitigates specific power quality problems. The Shunt Active Power Filter (SHAPF) is usually used to mitigate load problems such as source 
current harmonics due to non-linear and unbalanced load, power factor improvement, reactive power compensation, and voltage instability at the load side [17-22]. The Series Active Power Filter (SEAPF) is usually used to mitigate grid or mains problems, such as voltage sag, voltage swell, voltage dips, voltage unbalance, voltage interruption, phase shift, and voltage harmonics [23-37]. The unified power quality conditioner is utilized to solve all previous problems; it's called universal active power filter, and consists of a combination of shunt and series active power filter [38-39]. The hybrid active power filter is a combination of passive and active power filter, and is used for high power applications [40-46]. As mentioned above, only the unified power quality conditioner can mitigate all power quality problems. In this paper, the three phase three-wire SEAPF is used alone to mitigate effectively all power quality problems without using any shunt active or passive filter. The system under study consists of three phase distorted and unbalanced voltage source (programmable voltage source) supplying linear balanced load. Choosing linear loads to prove that the harmonics in source currents may exist due to distorted voltage source and not necessary exist due to nonlinear loads. Source current harmonics components will appear because of distorted voltage source. SHAPF is usually used beside SEAPF to mitigate source current harmonics, but by studying the system carefully it is obvious that, the existing source current harmonics is due to the distorted voltage source because of the load is linear and balanced load. So, using SEAPF alone is enough to eliminate power system problems and improve power quality. The SEAPF is mainly work as a voltage controller, voltage dynamic restorer and harmonic isolator. The SEAPF protects the customer from poor power quality. The design and modeling of series active power filter for compensation of harmonics and voltage controller are discussed.

\section{2- System Architecture}

The SEAPF is applied to act as a controlled voltage source. It reduces the terminal harmonic voltages, mitigates voltage dips, voltage sags, voltage harmonics, phase shift and voltage swells, and fed loads with a high quality voltage waveform. The high impedance imposed by the SEAPF is created by generating a voltage of the same frequency that the harmonics need to be vanished. Voltage unbalance is eliminated by compensating negativesequence and zero-sequence voltage components of the system [47]. The operation principle, control strategy, and MATLAB-SIMULINK results of the SEAPF are presented. Fig.1. shows the three phase SEAPF.

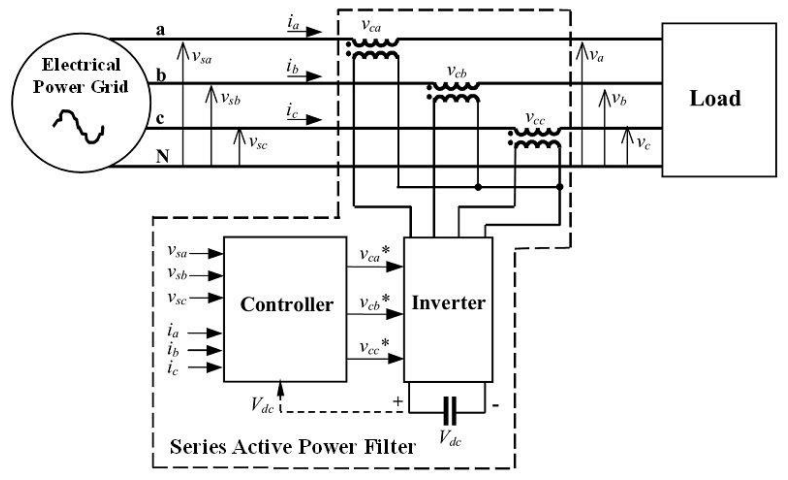

Fig.1 Three phase series active power filter. 


\section{3- Operation Principles}

In the system shown in fig.1, the purpose is to simultaneously compensate voltages unbalances and current harmonic components at the load terminals.

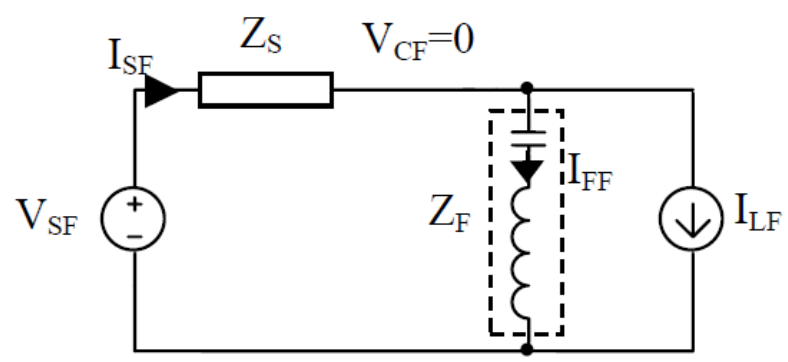

Fig.2 Equivalent circuit of fundamental frequencies.

In order to avoid the presence of harmonics at the source current, the active filter is controlled to present zero impedance at the fundamental frequency and high impedance at the frequencies of the load harmonics. Fig.2 shows the single phase equivalent circuit for fundamental harmonic, and fig. 3 for the rest of harmonics, where to simplify, an active filter is considered as an ideal controllable voltage source. The nonlinear load is represented by a current source $\mathrm{I}_{\mathrm{L}}$, the impedance of the passive filter is $\mathrm{Z}_{\mathrm{F}}$, and $\mathrm{Z}_{\mathrm{S}}$ is the source impedance.

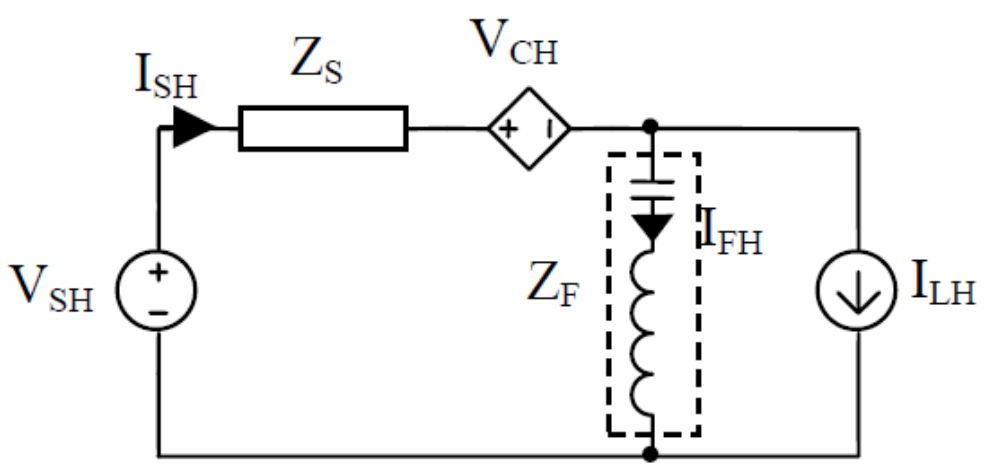

Fig.3 Equivalent circuit for harmonic frequencies.

The following equation is given for the circuit of the fig.3.

$$
\left(Z_{S}+Z_{F}\right) I_{S H}=Z_{F} I_{L H}+V_{S H}-V_{C H}
$$

To achieve high impedance at the frequencies of the load harmonics, the output voltage of the series active filter must be proportional to the source current harmonics, that is,

$$
V_{C H}=K I_{S H}
$$

So the harmonic current flowing at the source side is given by

$$
I_{S H}=\frac{Z_{F}}{\left(Z_{S}+Z_{F}+K\right)} I_{L H}+\frac{I}{\left(Z_{S}+Z_{F}+K\right)} V_{S H}
$$

When $\mathrm{K} \gg \mathrm{Z}_{\mathrm{S}}, \mathrm{Z}_{\mathrm{F}}$, then $\mathrm{I}_{\mathrm{SH}} \approx 0$

The compensation characteristic becomes ideal when the active filter presents an infinite impedance, $K=\infty$. In this way the passive filter problems, namely, the parallel resonance and the harmonic sink, are solved. 
The compensation characteristics of the SEAPF are mainly defined by the algorithm used to generate the reference signals required by the control system. These reference signals must allow current and voltage compensation with minimum time delay. It is important that the accuracy of the information contained in the reference signals allows the elimination of the current harmonics and voltage unbalances present in the power system. Since the voltage and current control scheme are independent, the equations used to calculate the voltage reference signals are the following [48]:

$$
\left[\begin{array}{l}
v_{a 0} \\
v_{a 1} \\
v_{a 2}
\end{array}\right]=\frac{1}{\sqrt{3}}\left[\begin{array}{ccc}
1 & 1 & 1 \\
1 & a & a^{2} \\
1 & a^{2} & a
\end{array}\right]\left[\begin{array}{l}
v_{a} \\
v_{b} \\
v_{c}
\end{array}\right]
$$

Where $\mathrm{v}_{\mathrm{a}}, \mathrm{v}_{\mathrm{b}}$ and $\mathrm{v}_{\mathrm{c}}$ correspond to the phase to neutral voltages before active filter, and $a=1 \angle-120$. All voltage related problems present in supply voltages are mitigated by controlling the SEAPF. The reference voltage signals are obtained by making the positivesequence component $\mathrm{V}_{\mathrm{a}}$ equal zero, and then applying the inverse of the Fortescue transformation. In this way the SEAPF compensates voltage unbalance. The reference signals for the voltage unbalance control scheme are obtained by applying the following equation:

$$
\left[\begin{array}{l}
v_{\text {refa }} \\
v_{\text {refb }} \\
v_{\text {refc }}
\end{array}\right]=\frac{1}{\sqrt{3}}\left[\begin{array}{ccc}
1 & 1 & 1 \\
1 & a^{2} & a \\
1 & a & a^{2}
\end{array}\right]\left[\begin{array}{c}
-v_{a 0} \\
0 \\
-v_{a 2}
\end{array}\right]
$$

Where $v_{a 0}$ is the zero-sequence component of voltage, and $v_{a 2}$ is the voltage negativesequence component [49]. Figure 4 shows the control scheme for obtaining the reference signal. This signal is generated by the PWM inverter. The gain $K_{v}$ is the turn ratio of the series transformers, which is applied to the reference signals for the voltage unbalance. The gain $K_{i}$ is the proportional constant for the harmonics of the source current; it gets the magnitude of the impedance for high frequency. Thus, the inverter must generate the following waveform.

$$
v_{c}=K_{i} i_{r e f}+K_{v} v_{r e f}
$$

The gating signals of the inverter are generated by comparing the resultant reference signal with the output of the inverter through a bang-bang control [50].

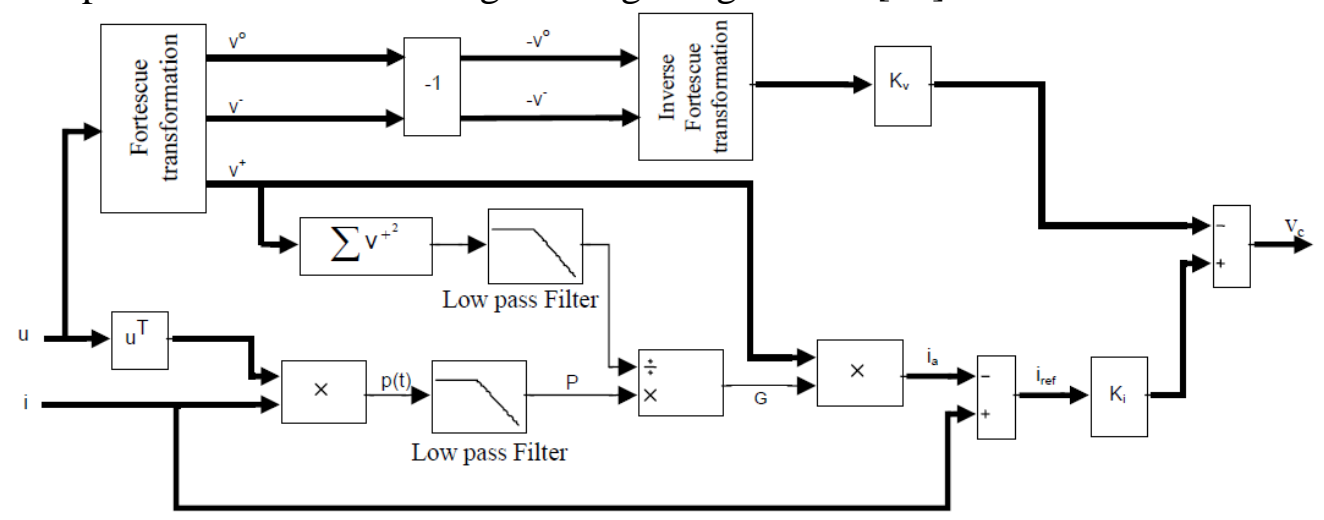

Fig.4 Blocks diagram of the control scheme.

\section{4- MATLAB-SIMULINK Model}

Fig.5 displays the MATLAB-SIMULINK model for the system under study [51-52] which consists of, 3-phase distorted voltage source (5th and 7th harmonic orders are 
included, voltage sag, and voltage swell), the harmonics and unbalanced (Sags and Swells) can be obtained by three phase programmable voltage source, 3-phase RL linear load, 3Phase-SEAPF connected to the system at the point of common coupling through a 3-phase coupling transformer, and measuring devices as shown in fig.5. The system components are listed in Table 1.

Table 1. System parameters

\begin{tabular}{|c|c|c|c|}
\hline Component & \multicolumn{2}{|c|}{ Parameter } & Value \\
\hline \multirow{5}{*}{ Voltage Source } & \multicolumn{2}{|c|}{ Voltage (line to line) rms } & $380 \mathrm{~V}$ \\
\hline & \multicolumn{2}{|c|}{ Frequency } & $50 \mathrm{~Hz}$ \\
\hline & \multicolumn{2}{|c|}{ Connection } & $\begin{array}{l}\text { Y neutral } \\
\text { grounded }\end{array}$ \\
\hline & \multirow[b]{2}{*}{ Harmonics } & $\begin{array}{c}\text { Order(n), } \\
\text { Amplitude(pu) }\end{array}$ & $\begin{array}{llll}5 & 0.2 & 0 & 2\end{array}$ \\
\hline & & $\begin{array}{c}\text { Phase(degrees) } \\
\text {, Seq(0,1 or } \\
2)\end{array}$ & $\begin{array}{llll}7 & 0.05 & 0 & 1\end{array}$ \\
\hline \multirow{2}{*}{ Load } & \multicolumn{2}{|c|}{ Three phase R } & $5 \Omega$ \\
\hline & \multicolumn{2}{|c|}{ Three phase L } & $15 \mathrm{mH}$ \\
\hline \multirow{3}{*}{$\begin{array}{l}\text { Series Active } \\
\text { Filter }\end{array}$} & \multicolumn{2}{|c|}{ Inverter DC voltage } & $\mathrm{VDC}=700 \mathrm{~V}$ \\
\hline & \multicolumn{2}{|c|}{ Series Resistance } & Rseries $=1 \Omega$ \\
\hline & \multicolumn{2}{|c|}{ Series Capacitance } & $\begin{array}{c}\text { Cseries }=100 \\
\mu \mathrm{F}\end{array}$ \\
\hline
\end{tabular}

Fig.6 shows the components of the SEAPF, which consists of three phase inverter, and 3 single phase coupling transformers.

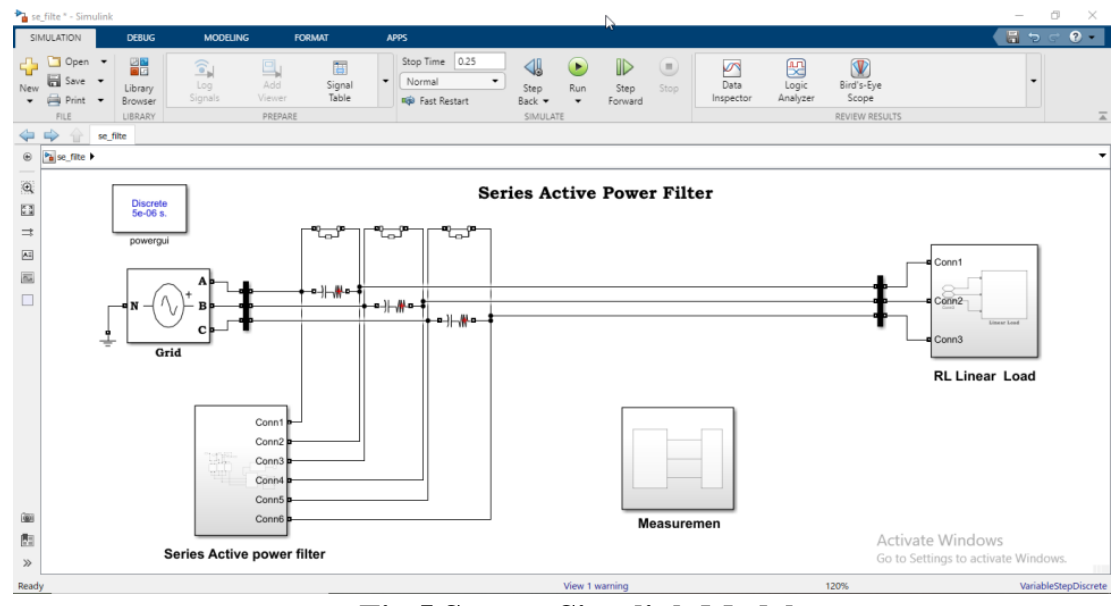

Fig.5 System Simulink Model.

The simulation model shows the mitigation effect of voltage sag, voltage swell, voltage harmonics, and source current harmonics before and after connecting the SEAPF.

The overall simulation time is $0.25 \mathrm{sec}$. The simulation starts at $0 \mathrm{sec}$ with voltage amplitude value $=1 \mathrm{p} . \mathrm{u}$, and at $\mathrm{t}=0.05 \mathrm{sec}$, the voltage sag value $=0.5 \mathrm{p} . \mathrm{u}$, and at $\mathrm{t}=0.1 \mathrm{sec}$, the voltage amplitude value $=1 \mathrm{p} . \mathrm{u}$, and at $\mathrm{t}=0.15 \mathrm{sec}$, the voltage swell value $=1.5 \mathrm{p} . \mathrm{u}$, and at $\mathrm{t}=0.2 \mathrm{sec}$, the voltage amplitude value $=1$ p.u and stay 1 p.u until the end of simulation.

Fifth and seventh (5th and 7th) voltage harmonic order are generated all simulation time (from $0 \mathrm{sec}$ to $0.25 \mathrm{sec}$ ). 


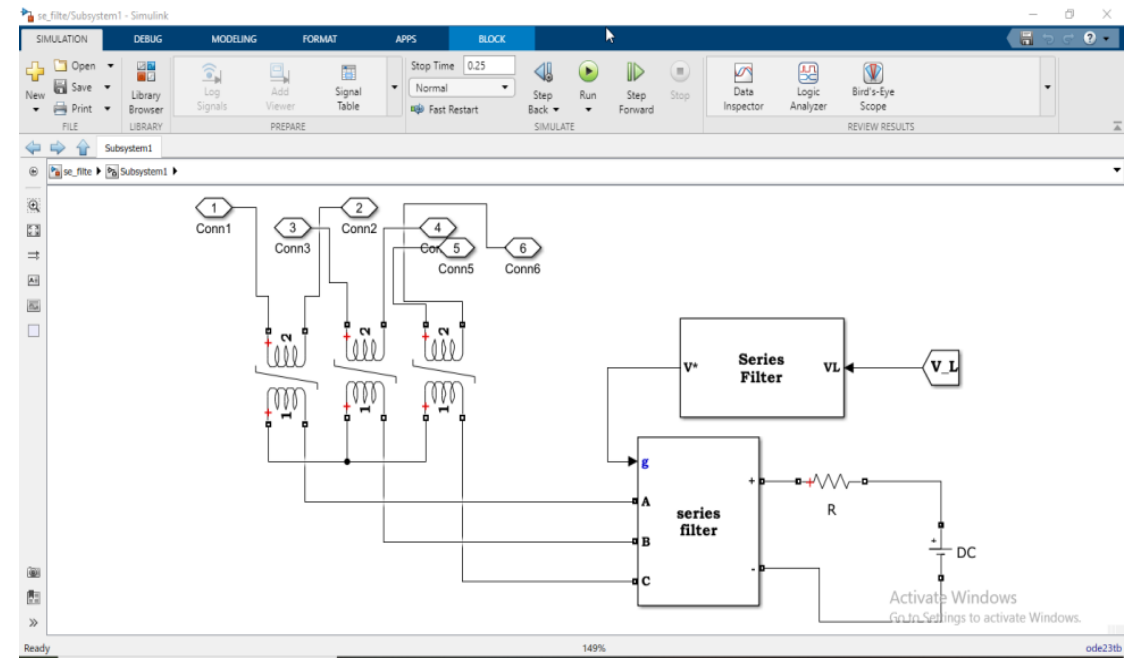

Fig.6 Simulink Model of the SEAPF.

\section{5- Simulation Results}

There are two study cases to show the waveforms of source voltage and source current before and after connecting the SEAPF, and compare between two cases to show the effect of SEAPF on mitigating voltage and current problems, and power quality improvement.

\section{A- Before connecting Series Active Power Filter}

First case study, running the whole power system simulation model without connecting the SEAPF. Figs. 7-9, show distorted source voltage and distorted source current waveform, FFT analysis of source voltage, and FFT analysis of source current respectively.
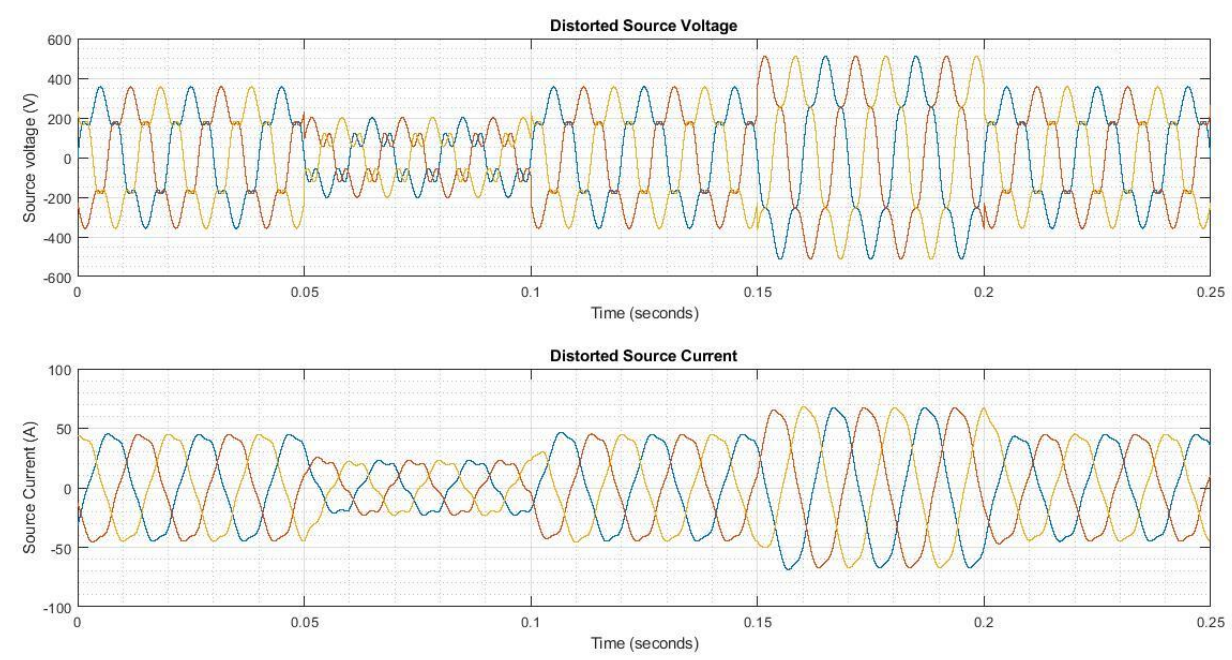

Fig.7 Source voltage vs. Source current before connecting SEAPF. 


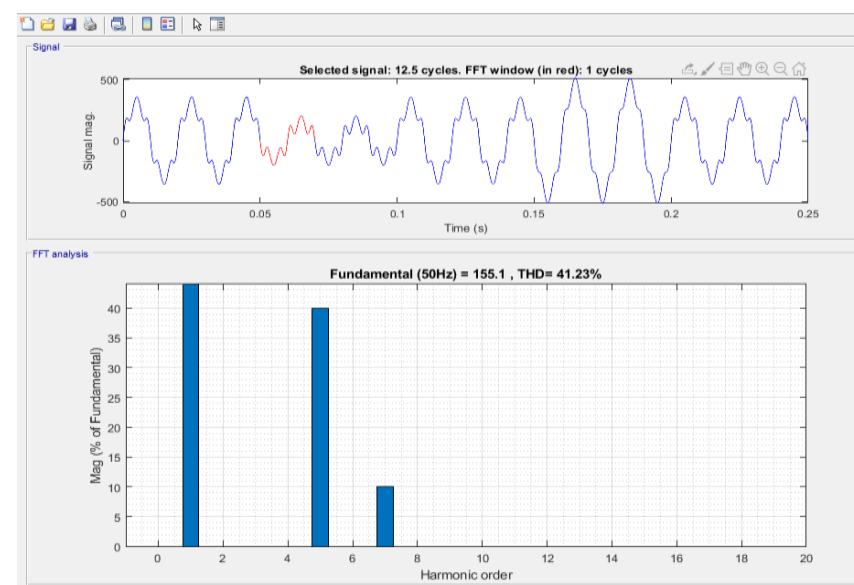

Fig.8 FFT analysis of distorted Source Voltage.

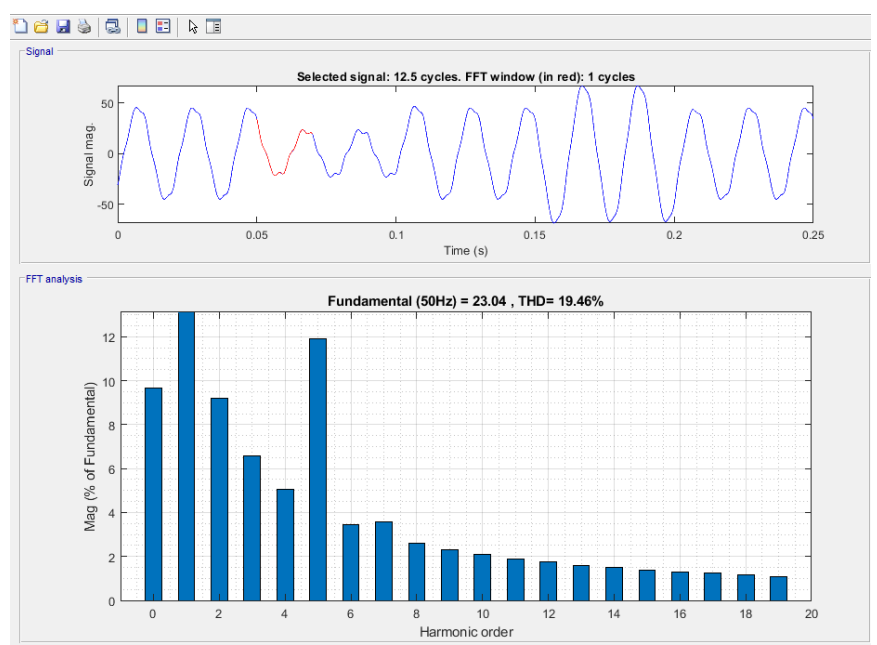

Fig.9 FFT analysis of distorted Source Current.

As shown in figs. 7-9, a great distortion of source voltage and source current, the source voltage is distorted because of voltage sags, voltage swells, and voltage harmonics. The THD\% of source voltage is $41.23 \%$, this THD\% of source voltage is too high and out of standard limits. The source current harmonic is also distorted, and the THD\% of source current is $19.46 \%$. The THD\% of source current is also out of the standard limits.

Table 2: shows the THD\% of source voltage and source current before connecting the SEAPF.

Table 2. THD\% of source voltage and source current

\begin{tabular}{|c|c|}
\hline Source Voltage THD\% & Source Current THD\% \\
\hline 41.23 & 19.46 \\
\hline
\end{tabular}

\section{B- $\quad$ After connecting Series Active Power Filter}

Second case study, running the whole power system simulation model with connecting the SEAPF. Figs. 10-14, show pure source voltage and pure source current waveforms, injected voltage waveform of SEAPF, FFT analysis of source voltage, FFT analysis of source current, and FFT analysis SEAPF injected voltage respectively. 

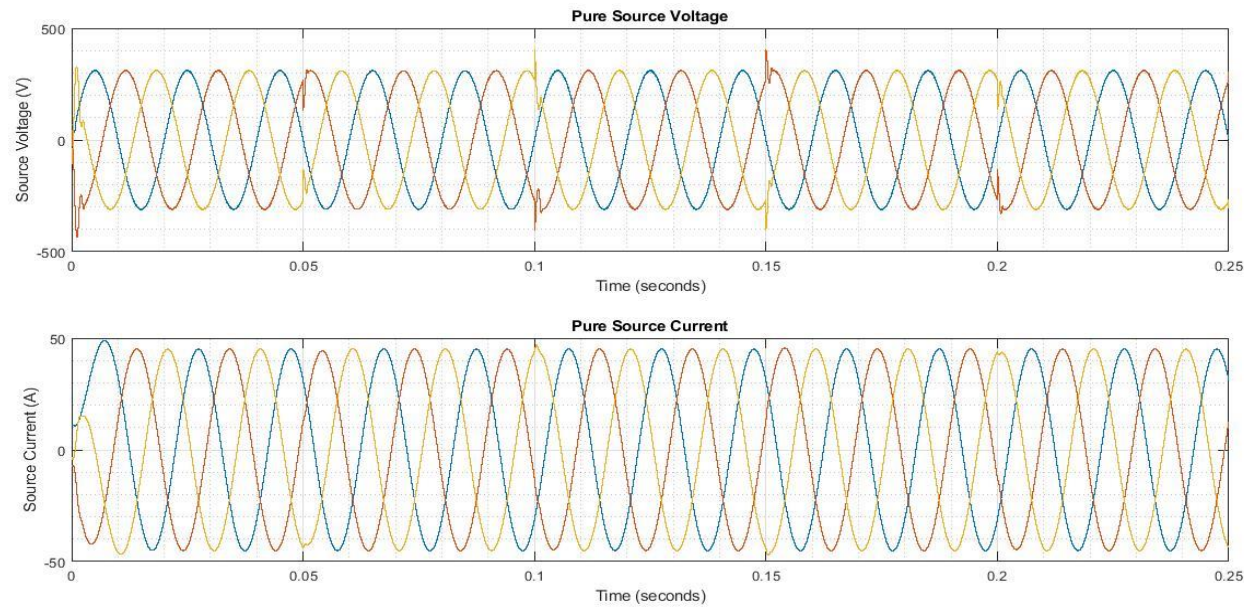

Fig.10 Source voltage vs. Source current after connecting SEAPF.

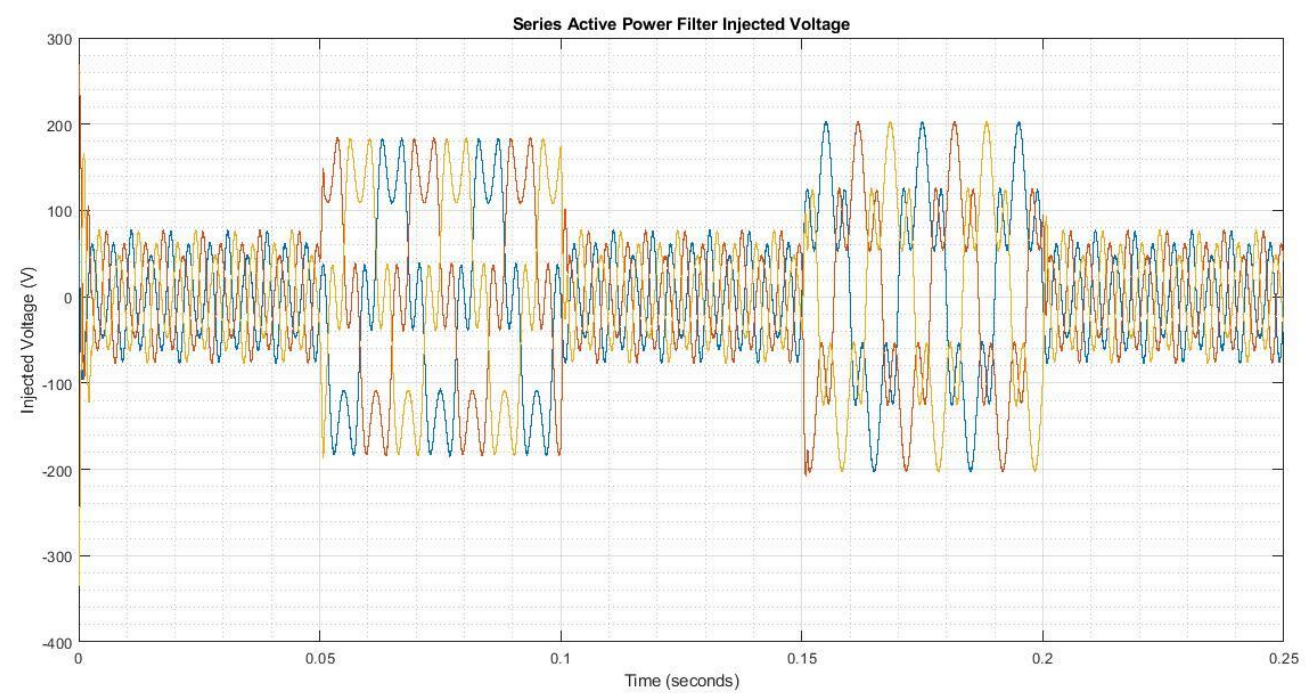

Fig.11 Injected voltage waveform of SEAPF.

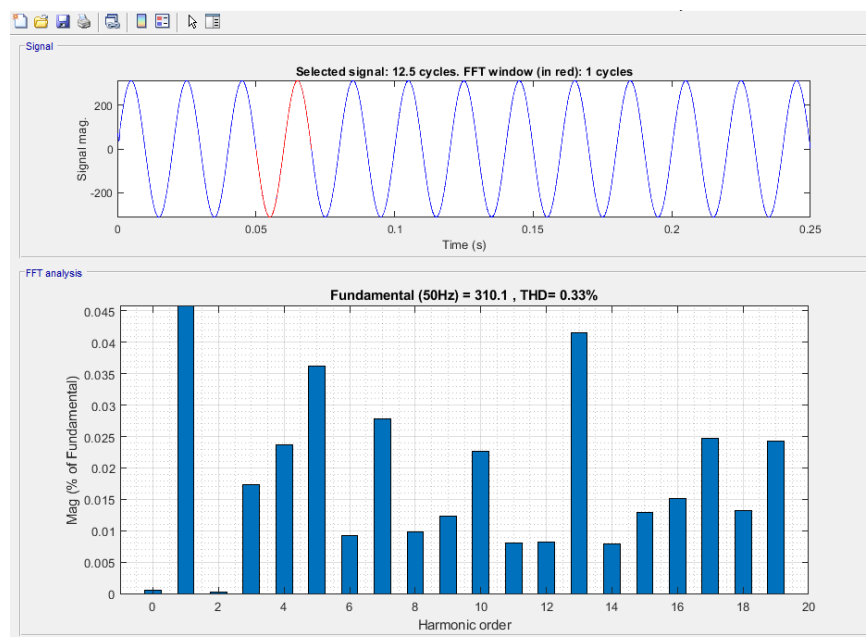

Fig.12 FFT Analysis of Pure Source Voltage. 


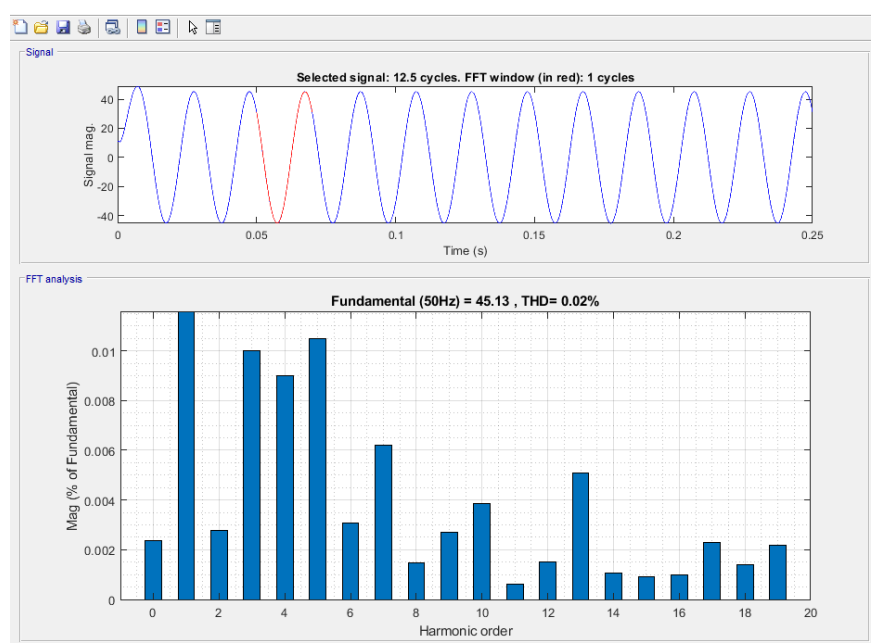

Fig.13 FFT Analysis of Pure Source Current.

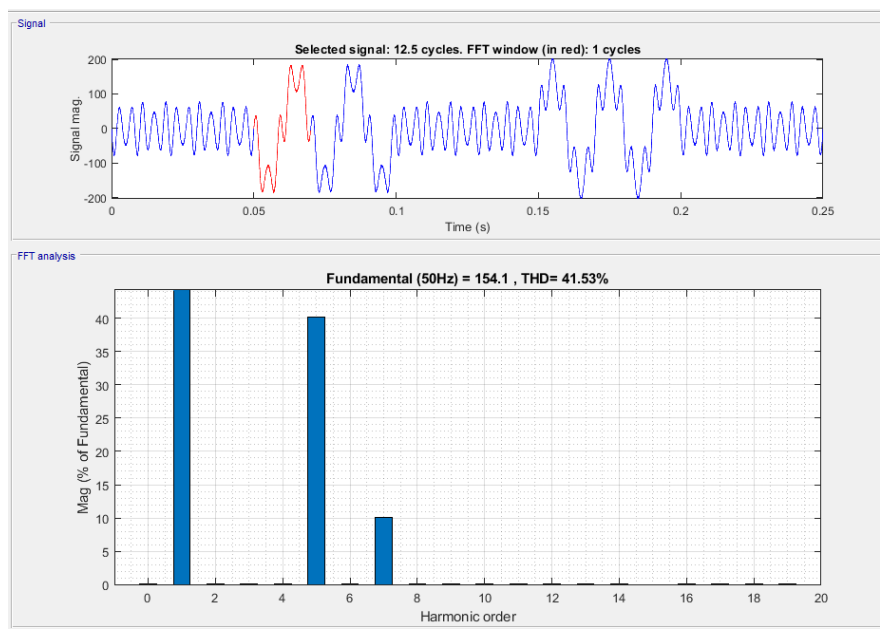

Fig.14 FFT Analysis of SEAPF Injected Voltage.

As shown in figures 10-14, the SEAPF eliminates the distortion of source voltage and source current. The THD\% of source voltage becomes $0.33 \%$, and the THD $\%$ of source current becomes $0.02 \%$. Table 3 shows the THD\% of source voltage and source current after connecting the SEAPF.

Table 3. THD\% source voltage and source current

\begin{tabular}{|c|c|}
\hline Source Voltage THD\% & Source Current THD\% \\
\hline 0.33 & 0.02 \\
\hline
\end{tabular}

After connecting the SEAPF, it is noticed that, 1) the SEAPF has a good effect on source current harmonic elimination; 2) the THD\% of source current is within the standard limits, 3) the THD\% of source voltage is within the standards limits [53-54], 4) the SEAPF mitigate all voltage problems.

Table 4 shows comparison of the THD\% of source voltage and source current before and after connecting the SEAPF. 
Table 4. Comparison of THD\% of source voltage and source current

\begin{tabular}{|c|c|c|}
\hline & $\begin{array}{c}\text { Before connecting } \\
\text { SEAPF }\end{array}$ & $\begin{array}{c}\text { After connecting } \\
\text { SEAPF }\end{array}$ \\
\hline $\begin{array}{c}\text { Source voltage } \\
\text { THD\% }\end{array}$ & 41.23 & 0.33 \\
\hline $\begin{array}{c}\text { Source } \\
\text { Current THD\% }\end{array}$ & 19.46 & 0.02 \\
\hline
\end{tabular}

\section{6- Conclusion}

In this case study, the Series Active Power Filter can be used alone to mitigate power system problems (voltage and current problems), and improve all power system quality. When using the SEAPF for the system under study, it is noticed that, 1) The SEAPF has a good effect on the source current harmonic elimination, 2) the THD\% of the source current is within the standard limits, 3) the THD\% of the source voltage is within the standard limits, 4) the SEAPF mitigates all voltage problems, 5) no need to use another filter (shunt or series and active or passive) for current harmonics elimination, 6) the SEAPF can be used alone as a power quality conditioner.

As shown in Table 4, the THD\% of source voltage and source current under distorted voltage source and linear load matches the standard limits.

\section{Acknowledgements}

I would like to express my deeply gratitude and appreciation to Prof. Dr. Hamdy Saleh Khalil El-Gohary, who choose the topic of the thesis, give all required guidelines, support and assistance during the whole period of preparation of the thesis. Finally, I gratefully acknowledge and thank my parents and wife for their patience, understanding and encouragement during the research period.

\section{References}

[1] Das, S. R., Ray, P. K., \& Mohanty, A. (2017). Enhancement of power quality disturbances using hybrid power filters. April. 2017 International Conference on Circuit ,Power and Computing Technologies (ICCPCT). DOI: 10.1109/ICCPCT.2017.8074275

[2] Harirchi, F., \& Simoes, M. G. Nov. (2018). Enhanced Instantaneous Power Theory Decomposition for Power Quality Smart Converter Applications. IEEE Transactions on Power Electronics, 33(11), 93449359 . DOI: $10.1109 /$ TPEL.2018.2791954.

[3] Elphick, S., Ciufo, P., Drury, G., Smith, V., Perera, S., \& Gosbell, V. April (2017). Large Scale Proactive Power-Quality Monitoring: An Example From Australia. IEEE Transactions on Power Delivery, 32(2), 881-889. DOI: 10.1109/TPWRD.2016.2562680.

[4] Singh, S., Singh, B., Bhuvaneswari, G., \& Bist, V. Sept (2015). Power Factor Corrected Zeta Converter Based Improved Power Quality Switched Mode Power Supply. IEEE Transactions on Industrial Electronics, 62(9), 5422-5433. DOI: 10.1109/TIE.2015.2415752.

[5] Shin, Y.-J., Powers, E. J., Grady, M., \& Arapostathis, A. (2006). Power Quality Indices for Transient Disturbances. Jan 2006 IEEE Transactions on Power Delivery, 21(1), 253-261. DOI: $10.1109 /$ TPWRD.2005.855444.

[6] Dash, S. K., \& Ray, P. K. Sept (2018). Power Quality Improvement Utilizing PV Fed Unified Power Quality Conditioner Based on UV-PI and PR-R Controller. CPSS Transactions on Power Electronics and Applications, 3(3), 243-253. DOI: 10.24295/CPSSTPEA.2018.00024.

[7] Xu, Q., Ma, F., Luo, A., He, Z., \& Xiao, H. Dec. (2016). Analysis and Control of M3C-Based UPQC for Power Quality Improvement in Medium/High-Voltage Power Grid. IEEE Transactions on Power Electronics, 31(12), 8182-8194. DOI: 10.1109/TPEL.2016.2520586

[8] Elphick, S., Gosbell, V., Smith, V., Perera, S., Ciufo, P., \& Drury, G. April (2017). Methods for Harmonic Analysis and Reporting in Future Grid Applications. IEEE Transactions on Power Delivery, 
32(2), 989-995. DOI: 10.1109/TPWRD.2016.2586963.

[9] Asad Ullah, Inam Ul Hasan Sheikh, Shahzad Arshad, Faisal Saleem, Digital Active Power Filter Controller Design for Current Harmonics in Power System, Proceedings of 2019 16th International Bhurban Conference on Applied Sciences \& Technology (IBCAST) Islamabad, Pakistan, 8th - 12th January, 2019. DOI: 10.1109/IBCAST.2019.8667169.

[10] Devassy, S., \& Singh, B. (2017). Control of solar energy integrated active power filter in weak grid system. Dec. 2017 7th International Conference on Power Systems (ICPS). DOI: 10.1109/ICPES. 2017. 8387359.

[11] Yuan, H., \& Jiang, X. (2016). A simple active damping method for Active Power Filters. March. 2016 IEEE Applied Power Electronics Conference and Exposition (APEC). DOI: 10.1109/APEC.2016. 7467979.

[12] Bai, H., Wang, X., \& Blaabjerg, F. (2017). A grid-voltage-sensorless resistive active power filter with series LC-filter.May.2018 IEEE Transactions on Power Electronics (Volume: 33, Issue: 5 , May 2018 ). doi:10.1109/ecce.2017.8096551. DOI: 10.1109/TPEL.2017.2717183.

[13] Ehtesham, M., \& Jamil, M. (2017). Enhancement of Power Quality Using Active Power Filter for PV Systems with Model Based MPPT. Dec. 2017 14th IEEE India Council International Conference (INDICON).DOI: $10.1109 /$ INDICON.2017.8487544.

[14] Marcu, M., Popescu, F.-G., Niculescu, T., Pana, L., \& Handra, A. D. (2014). Simulation of power active filter using instantaneous reactive power theory. May. 2014 16th International Conference on Harmonics and Quality of Power (ICHQP). DOI: 10.1109/ICHQP.2014.6842783.

[15] Chen, N., Yu, S., Gao, L., Huang, Y., \& Chen, R. Suppressing Interference Peak in an Active Power Filter via Periodic Carrier Frequency Modulation Based on a Spectrum Analysis Approach. Dec. 2019, IEEE Transactions on Electromagnetic Compatibility, 1-11.DOI: 10.1109/TEMC.2018.2883338.

[16] Zadeh, J. K., \& Farjah, E. (2009). New control technique for compensation of neutral current harmonics in three-phase four-wire systems. July. 2009 IEEE Bucharest PowerTech. DOI: $10.1109 /$ PTC.2009.5281802.

[17] Patil, S. S., Metri, R. A., \& Shinde, O. K. (2017). Shunt active power filter for MV 12-pulse rectifier using PI with SMC controller. April. 2017 International Conference on Circuit ,Power and Computing Technologies (ICCPCT). DOI: 10.1109/ICCPCT.2017.8074260.

[18] Taher, S. A., Alaee, M. H., \& Dehghani Arani, Z. (2017). Model predictive control of PV-based shunt active power filter in single phase low voltage grid using conservative power theory. Feb. 2017 8th Power Electronics, Drive Systems \& Technologies Conference (PEDSTC). DOI: 10.1109 /PEDSTC.2017.7910332.

[19] Buyuk, M., Tan, A., Inci, M., \& Tumay, M. (2017). A notch filter based active damping of llcl filter in shunt active power filter. Oct. 2017 International Symposium on Power Electronics (Ee).DOI: $10.1109 /$ PEE.2017.8171701.

[20] Vibhute, K. (2015). Efficient shunt active power filter for harmonic suppression — A Matlab/Simulink approach. Sept. 2015 International Conference on Computer, Communication and Control (IC4). DOI: $10.1109 /$ IC4.2015.7375513.

[21] Patil, S. S., \& Metri, R. A. (2017). Power quality improvement using shunt active power filter. Feb. 2017 International Conference on Data Management, Analytics and Innovation (ICDMAI). DOI: $10.1109 /$ ICDMAI.2017.8073501.

[22] Gautam, S., \& Aeidapu, M. (2019). Sine Cosine Algorithm Based Shunt Active Power Filter For Harmonic Compensation. June. 2019 3rd International Conference on Electronics, Communication and Aerospace Technology (ICECA). DOI: 10.1109/ICECA.2019.8821800.

[23] P. Salmerón and S. P. Litrán, "Improvement of the Electric Power Quality Using Series Active and Shunt Passive Filters", IEEE Transactions on Power Delivery, vol. 25, no. 2, April 2010, pp-10581067. DOI: 10.1109/TPWRD.2009.2034902.

[24] Javad Gholinezhad, Navid Aghli, "A new control strategy for Series Active Filter to improve lowfrequency oscillations damping”, IEEE 2016, 21 st Electrical Power Distribution ConferencenMay 2016, Karaj- Alborz- Iran. DOI: 10.1109/EPDC.2016.7514801.

[25] Torre, J. L., Barros, L. A. M., Afonso, J. L., \& Pinto, J. G. (2019). Development of a Proposed Single- 
Phase Series Active Power Filter without External Power Sources. Sept. 2019 International Conference on Smart Energy Systems and Technologies (SEST). DOI: 10.1109/SEST.2019.8849010.

[26] Hashim, H. F., Omar, R., \& Rasheed, M. (2016). Design and analysis of a three phase series active power filter (SAPF) based on hysteresis controller. Nov. 2016, 4th IET Clean Energy and Technology Conference (CEAT 2016) .DOI: 10.1049/cp.2016.1310.

[27] Pan, Z., Peng, F. Z., \& Wang, S. (2005). Power Factor Correction Using a Series Active Filter. Jan. 2005 IEEE Transactions on Power Electronics, 20(1), 148-153.DOI: 10.1109/TPEL.2004.839819.

[28] Ribeiro, E. R., \& Barbi, I. (2006). Harmonic Voltage Reduction Using a Series Active Filter Under Different Load Conditions. Sept. 2006, IEEE Transactions on Power Electronics, 21(5), 13941402.DOI: $10.1109 /$ TPEL.2006.880265.

[29] Inoue, S., Shimizu, T., \& Wada, K. (2007). Control Methods and Compensation Characteristics of a Series Active Filter for a Neutral Conductor. Feb. 2007, IEEE Transactions on Industrial Electronics, 54(1), 433-440.DOI: 10.1109/TIE.2006.885511.

[30] Meloni, L. F. J., Tofoli, F. L., Rezek, A. J. J., \& Ribeiro, E. R. (2019). Modeling and Experimental Validation of a Single-Phase Series Active Power Filter for Harmonic Voltage Reduction. Oct. 2019, IEEE Access, 7, 151971-151984.DOI: 10.1109/ACCESS.2019.2947917.

[31] Lee, G.-M., Lee, D.-C., \& Seok, J.-K. (2004). Control of Series Active Power Filters Compensating for Source Voltage Unbalance and Current Harmonics. Feb. 2004, IEEE Transactions on Industrial Electronics, 51(1), 132-139.DOI: 10.1109/TIE.2003.822040.

[32] Ravikumar, A., Mohan, N., \& Soman, K. . (2018). Performance Enhancement of a Series Active Power Filter using Kalman Filter based Neural Network Control Strategy. Sept. 2018 International Conference on Advances in Computing, Communications and Informatics (ICACCI). DOI: 10.1109/ICACCI. 2018.8554889.

[33] Xianfeng Chen, Tingkang Wang, Haifei Wang . A Magnetic Flux Compensated Series Active Power Filter using Deadbeat Control based on Repetitive Predictor Theory. Aug. 2019 22nd International Conference on Electrical Machines and Systems (ICEMS). DOI: 10.1109/ICEMS.2019.8922094.

[34] Khade, B. R., \& Virulkar, V. B. (2015). Mitigation of harmonics in a neutral conductor for three-phase four-wire distribution system using series active power filter. March. 2015 IEEE International Conference on Electrical, Computer and Communication Technologies (ICECCT).DOI: $10.1109 /$ ICECCT.2015.7225998.

[35] Chaudhari, M. M. A., \& Chandraprakash. (2012). Three-phase Series Active Power Filter as Power Quality Conditioner.Dec. 2012 IEEE International Conference on Power Electronics, Drives and Energy Systems (PEDES). DOI: 10.1109/PEDES.2012.6484387.

[36] Hashim, H. F., Omar, R., \& Rasheed, M. (2016). Design and analysis of a three phase series active power filter (SAPF) based on hysteresis controller. Nov. 2016 4th IET Clean Energy and Technology Conference (CEAT 2016) . DOI: 10.1049/cp.2016.1310.

[37] Toth, B., \& Puklus, Z. (2010). Series active filters - Spice simulation. Nov. 201011 th International Symposium on Computational Intelligence and Informatics (CINTI). DOI: 10.1109/CINTI. 2010. 5672244.

[38] Jong-Kun Lee, Jul-Ki Seok, \& Dong-Choon Lee. (n.d.). Unified active power filters for source voltage unbalance/current harmonics compensation and power factor correction. Nov. 2004, 30th Annual Conference of IEEE Industrial Electronics Society, 2004. IECON 2004. DOI: 10.1109/IECON. 2004.1433366.

[39] Nohara, K., Ueda, A., Torii, A., \& Doki, K. (2007). Compensating Characteristics of a Series-Shunt Active Power Filter Considering Unbalanced Source Voltage and Unbalanced Load. April. 2007 Power Conversion Conference - Nagoya. DOI: 10.1109/PCCON.2007.373190.

[40] Chen, B., Zhang, C., Tian, C., Wang, J., \& Yuan, J. June (2016). A Hybrid Electrical Magnetic Power Quality Compensation System With Minimum Active Compensation Capacity for V/V Cophase Railway Power Supply System. IEEE Transactions on Power Electronics, 31(6), 4159-4170. DOI: $10.1109 /$ TPEL.2015.2477459.

[41] Daftary, D., \& Shah, M. T. Dee. (2019). Design and Analysis of Hybrid Active Power Filter for Current Harmonics Mitigation. 2019 IEEE 16th India Council International Conference (INDICON). 
DOI: $10.1109 /$ INDICON47234.2019.9029052.

[42] Rahmani, S., Hamadi, A., Al-Haddad, K., \& Dessaint, L. A. (2014). A Combination of Shunt Hybrid Power Filter and Thyristor-Controlled Reactor for Power Quality. May. 2014 IEEE Transactions on Industrial Electronics, 61(5), 2152-2164.DOI: 10.1109/TIE.2013.2272271

[43] Kedra, B. (2015). Reducing inverter power rating in active power filters using proposed hybrid power filter topology. June. 2015 IEEE 15th International Conference on Environment and Electrical Engineering (EEEIC).DOI: 10.1109/EEEIC.2015.7165203.

[44] Cleary-Balderas, A., Senior, A. M.-R., \& Cruz-Hernendez, O. (2016). Hybrid active power filter based on the IRP theory for harmonic current mitigation. Nov. 2016 IEEE International Autumn Meeting on Power, Electronics and Computing (ROPEC). DOI: 10.1109/ROPEC.2016.7830608.

[45] Javadi, A., Hamadi, A., Woodward, L., \& Al-Haddad, K. (2016). Experimental Investigation on a Hybrid Series Active Power Compensator to Improve Power Quality of Typical Households. Aug. 2016, IEEE Transactions on Industrial Electronics, 1-1.DOI: 10.1109/TIE.2016.2546848.

[46] Yang-Wen Wang, Man-Chung Wong, \& Chi-Seng Lam. (2015). Historical review of parallel hybrid active power filter for power quality improvement. TENCON 2015 - Nov. 2015 IEEE Region 10 Conference. DOI: $10.1109 /$ TENCON.2015.7373190.

[47] Sharma, A., Sharma, S. K., \& Singh, B. (2018). Unified Power Quality Conditioner Analysis Design and Control. Sept. 2018 IEEE Industry Applications Society Annual Meeting (IAS). DOI: $10.1109 /$ IAS.2018.8544566.

[48] Kumar, K. P., \& Ilango K. (2014). Design of series active filter for power quality improvement. Nov. 2014 International Conference on Electronics, Communication and Computational Engineering (ICECCE).DOI: 10.1109/ICECCE.2014.7086639.

[49] Kim, Y. S., Kim, J. S., \& Ko, S. H. (2004). Three-phase three-wire series active power filter, which compensates for harmonics and reactive power. May. 2004, IEE Proceedings - Electric Power Applications, 151(3), 276.DOI: 10.1049/ip-epa:20040208.

[50] Salvador P. Litrán, Patricio Salmerón, Jesús R. Vázquez and Juan L. Flores. Compensation of Voltage Unbalance and Current Harmonics with a Series Active Power Filter. RE\&PQJ, Vol. 1, No.3, March 2005. doi.org/10.24084/repqj03.257.

[51] G. Rajpriya, Dr.S. Ravi, and Ahmad Mujahid A. Zaidi," Design and development of MATLAB Simulink based Selective Harmonic Elimination technique for three phase voltage source inverter", 2013 International Conference on Advanced Computing and Communication Systems (ICACCS 2013), Dec. 19 - 21, 2013, Coimbatore, INDIA. DOI: 10.1109/ICACCS.2013.6938734.

[52] SIMULINK: The Dynamic System Simulation Software-User's Guide, the MathWorks Inc. April 1993.

[53] IEEE, "Recommended Practices and Requirements for Harmonic Control in Electrical Power Systems," in IEEE Std 519-1992, pp. 1-112, 9 Apr. 1993.

[54] Electromagnetic compatibility (EMC)-Part 4-7: Testing and measurement techniques-General guide on harmonics and interharmonics measurements and instrumentation, for power supply systems and equipment connected thereto, IEC standard 61000-4-7, EMC, Oct. 2009. 